\title{
Pemanfaatan Batu Gunung Posi'padang Balla Kabupaten Mamasa Sebagai Campuran AC-BC
}

\author{
Newman Archimedes Salmon ${ }^{\star 1}$, Alpius ${ }^{\star 2}$, Charles Kamba ${ }^{\star 3}$ \\ *1 Mahasiswa Program Studi Teknik Sipil, Universitas Kristen Indonesia Paulus, Makassar, Indonesia \\ archimedes@gmail.com \\ *2,3 Dosen Program Studi Teknik Sipil, Universitas Kristen Indonesia Paulus, Makassar, Indonesia \\ alpiusnini@gmail.com dan kamba.charles@gmail.com
}

\begin{abstract}
ABSTRAK
Penelitian ini dimaksudkan untuk Memanfaatkan Batu Gunung Posi'padang Sebagai Bahan Campuran AC-BC. Metodologi dalam penelitian ini adalah melakukan serangkaian pengujian karakteristik agregat kasar, halus,dan filler kemudian merancang komposisi campuran Laston AC-BC serta pengujian Marshall untuk mendapatkan karakteristik campuran dan pengujian Marshall immersion untuk memperoleh indeks perendaman (IP) / Indeks kekuatan sisa (IKS)/ durabilitas campuran berkadar aspal optimum.

Hasil penelitian yang dilakukan di Laboratorium Jalan dan Aspal Fakultas Teknik Jurusan Teknik Sipil Universitas Kristen Indonesia Paulus Makassar, menunjukkan bahwa karakteristik bahan perkerasan berupa batu gunung Serang Tengnge Kecamatan Kapalapitu memenuhi spesifikasi sebagai bahan lapisan perkerasan jalan. Melalui Uji Marshall diperoleh karakteristik campuran Laston AC-WC dengan kadar aspal 5,0\%, 6, 0\%, 6, 50\%, 7,00\%, 7,50\%. Hasil pengujian Marshall immersion campuran laston AC-WC dengan kadar aspal optimum 7,0\% diperoleh Indeks Perendaman (IP)/ Indeks Kekuatan Sisa ( IKS)/Durabilitas sebesar 95,74 \% memenuhi persayatan yaitu 90\% dan memenuhi Spesifikasi Bina Marga 2018.
\end{abstract}

Kata kunci : Karakteristik agregat, Komposisi LASTON AC-BC, Marshall Test

\begin{abstract}
This research is intended to Utilize Posi Mountain Stone as a Mixed Material of AC-BC. The methodology in this research is to conduct a series of testing the characteristics of coarse, fine aggregate, and filler then design the composition of the Laston AC-BC mixture and Marshall test to obtain the mixture characteristics and Marshall immersion test to obtain an immersion index (IP) / residual strength index (IKS) / optimum durability of asphalt mixtures. The results of research conducted at the Road and Asphalt Laboratory of the Faculty of Engineering, Department of Civil Engineering, Christian University of Indonesia, Makassar Makassar, showed that the characteristics of pavement materials in the form of Serang Tengnge mountain rocks, Kapalapitu District, meet specifications as road pavement coating materials. Through the Marshall Test obtained the characteristics of the mixture Laston AC-WC with asphalt content of $5.0 \%, 6,0 \%, 6,50 \%$, $7.00 \%, 7.50 \%$. The Marshall immersion test results of the laston AC-WC mixture with an optimum asphalt content of $7.0 \%$ obtained an Immersion Index (IP) / Residual Strength Index (IKS) / Durability of $95.74 \%$, which fulfill $90 \%$ compliance and meet 2018 Highways Quality Specifications.
\end{abstract}

Keywords: Aggregate Characteristics, LASTON AC-BC Composition, Marshall Test

\section{PENDAHULUAN}

Batu gunung adalah batuan yang mengandung kapur dan banyak ditemukan di daerah dataran tinggi. Batu gunung juga kini banyak dimanfaatkan sebagai agregat untuk campuran konstruksi. Kebutuhan pembangunan prasarana jalan di tiap wilayah khususnya di Mamasa Kecamatan Balla semakin dikembangkan, maka dari itu kebutuhan material untuk pembangunan khususnya prasarana jalan semakin meningkat. Pembangunan prasarana jalan di Kabupaten Mamasa Kecamatan Balla selama ini banyak menggunakan bahan yang berasal dari luar kabupaten, misalnya dari Kabupaten Mamasa dan Kota Polewali Mandar. Kebutuhan biaya untuk mendatangkan agregat dari luar kabupaten membutuhkan biaya yang cukup besar. Untuk memenuhi kebutuhan tersebut maka perlu memanfaatkan sumber daya alam yang ada. Agregat batu Gunung Posi'padang sebagai salah satu kekayaan alam Kabupaten Mamasa tepatnya di Kecamatan Balla, yang berada di daerah tersebut diharapkan dapat menjadi bahan utama untuk agregat batu pecah (chipping), sehingga 
pemanfaatan batu pecah yang di daerah tersebut lebih optimal, untuk itu penggunaan bahan setempat perlu diprioritaskan karena ketersediaan suber daya alamnya yang melimpah.

Laston adalah suatu lapis permukaan yang terdiri dari campuran aspal keras dan agregat yang bergradasi menerus, dicampur, dihamparkan dan dipadatkan dalam kondisi panas dan suhu tertentu [1]. Laston bersifat kedap air, mempunyai nilai struktural, awet, kadar aspal berkisar 4-7\% terhadap berat campuran, dan dapat digunakan untuk lalu lintas ringan, sedang, hingga berat [2]. Campuran ini memiliki tingkat kekakuan yang tinggi. Menurut Sukirman (2007) aspal beton terbagi menjadi 3 macam campuran, yaitu laston lapis aus (AC-WC), laston lapis pengikat (AC-BC), dan laston lapis pondasi [2].

Lapis aspal beton biasanya digunakan untuk lapis permukaan, lapis perata, dan lapis pengikat. Dalam penggunaannya, ketiganya mempunyai perbedaan dalam persyaratan campuran. Agregat yang digunakan umumnya memiliki gradasi rapat, dan memiliki rongga udara antar agregat kecil dan memerlukan sedikit aspal [3]. Kerusakan yang sering terjadi pada beton aspal biasanya dimulai dengan adanya retak-retak pada perkerasan. Hal ini karena beton aspal memiliki rongga antar agregat yang kecil, sehingga volume aspal yang menyelimuti butiran agregat juga sedikit. Akibatnya aspal dengan mudah teroksidasi, lapisan kurang kedap air yang mengakibatkan aspal mudah terkelupas dari agregat yang menyebabkan terjadinya pelepasan butir [4].

Material yang digunakan pada campuran Laston berupa aspal, agregat kasar, agregat halus, dan filler. Aspal juga digunakan sebagai bahan pengikat aspal pada temperatur rendah akan menjadi benda padat atau semi padat, sedangkan aspal pada temperatur tinggi akan melunak. Penggunaan aspal pada penelitian menggunanakan aspal keras dengan penetrasi 60/70. Aspal keras adalah semen aspal yang dalam penggunaannya dipanaskan lebih dulu hingga menjadi cair sampai suhu tertentu, dan berbentuk padat pada suhu ruang sekitar 25$30^{\circ} \mathrm{C}$. Agregat kasar yaitu batuan yang tertahan saringan no. 4 (diameter 4,75 mm). Dalam pelaksanaan pengujian campuran aspal, agregat yang digunakan harus dari sumber dan jenis yang sama. Agregat kasar harus terdiri dari batu pecah atau kerikil pecah yang bersih, kering, kuat, awet dan bebas dari bahan lain yang mengganggu dan 95\% agregat kasar mempunyai muka bidang pecah satu atau lebih dan $90 \%$ agregat kasar mempunyai muka bidang pecah dua atau lebih. Agregat halus yaitu batuan yang lolos saringan no. 8 (diameter 2,38 $\mathrm{mm}$ ) dan tertahan saringan no. 200 (diameter $0,075 \mathrm{~mm}$ ). Agregat halus harus terdiri dari pasir alam atau pasir buatan atau pasir terak atau gabungan daripada bahan-bahan tersebut. Agregat halus harus bersih, kering, kuat, bebas dari gumpalan-gumpalan lempung dan bahan-bahan lain yang mengganggu serta terdiri dari butir-butir yang bersudut tajam dan mempunyai permukaan yang kasar. Filler atau bahan pengisi adalah material yang lolos saringan no. 200 (diameter $0,075 \mathrm{~mm}$ ). Bahan pengisi harus kering dan bebas dari bahan lain yang mengganggu. Kadar filler dalam campuran beton aspal akan berpengaruh pada proses pencampuran, penghamparan, dan pemadatan. Selain itu, filler mempengaruhi sifat elastisitas campuran dan sensitivitasnya terhadap air.

Pada penelitian ini, spesifikasi yang digunakan untuk merancang campuran menggunakan spesifikasi Bina Marga 2018 untuk pekerjaan jalan dan jembatan [5].

Peneliti sebelumnya yang meneliti tentang laston AC-BC antar lain Alpius (2019) meneliti Performance of Laston AC-WC Mixture Using Asbuton LGA and Fakfak Materials [6]. Kamba (2013), meneliti tentang Pengaruh Penentuan Kadar Aspal Optimum Terhadap Kualitas Desain Campuran Beraspal [7]. Tandibua at.al (2020) melakukan Study of Laston BC Durability and Permeability Using Coconut Shell Addition Materials [8]. Sumardi at.al (2019) melkukan Study of the Use Bagasse Ash as a Filler Replacement to Characteristics Asphalt Concrete [9]. Penelitian yang meneliti tentang penggunaan material local diantaranya, Alpius (2019) meneliti tentang Campuran HRS-WC Menggunakan Agregat Batu Gunung Desa Palipu Kecamatan Mengkendek Tana Toraja, Rachman (2020) meneliti Pemanfaatan Batu Gunung Bottomale Toraja Utara sebagai Campuran Laston [10]. Fani at.el (2019) meneliti tentang Pemanfaatan Agregat Sungai Wanggar Kabupaten Nabire Sebagai Bahan Campuran AC-WC dan AC-BC [11]. Kamba (2018) meneliti Marshall Characteristics Test On Hot Rolled Sheet Base Combine Using Nickel Slag For Half Gap Graded [12].

Tujuan dari penelitian ini adalah Mengetahui karakteristik agregat, merancang komposisi dan karakteristik campuran melalui pengujian Marshall konvensional dan nilai indeks kekuatan sisa melalui pengujian Marshall immersion.

\section{METODE PENELITIAN}

\section{Lokasi dan Waktu Penelitian}

Lokasi pengambilan material adalah Gunung Posi'padang terletak di desa Posi'padang, Kecamatan Balla, Kabupaten Mamasa, Lokasi ini terletak 5 km dari Kota Mamasa. Lokasi penelitian dapat lihat pada gambar 1 . 


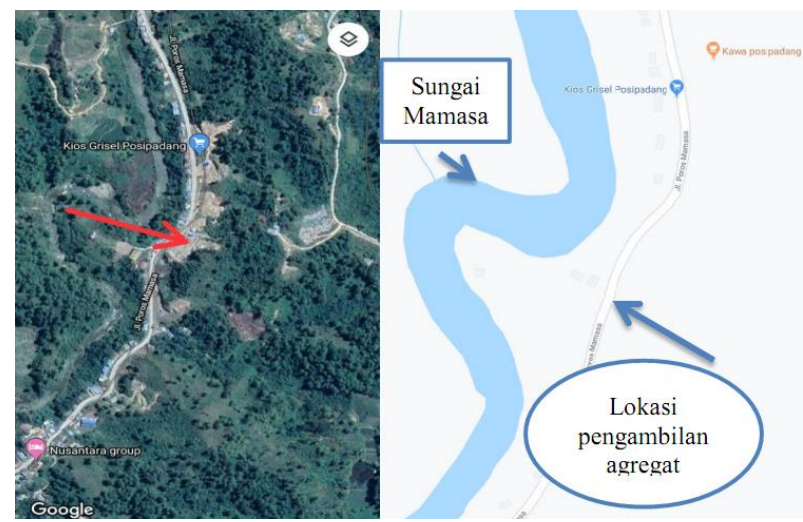

Gambar 1. Lokasi Penelitian

\section{Pemeriksaan Karakteristik Agregat}

Pemeriksaan karakteristik agregat dilakukan terhadap pengujian Analisa Saringan (SNI ASTM C136:2012), pengujian ini bertujuan untuk membuat suatu distribusi ukuran agregat kasar dalam bentuk grafik yang dapat memperlihatkan pembagian butir (gradasi) suatu agregat dengan menggunakan saringan.

Pemeriksaan Berat Jenis Curah (Bulk) dan Penyerapan Air Agregat kasar (SNI 1969: 2016), dan Agregat Halus (SNI 1970:2016). Maksud dari pemeriksaan ini ialah menetukan nilai berat jenis dan penyerapan agregat kasar dan mengelompokkannya berdasarkan berat jenisnya.

Pemeriksaan Kadar Lumpur (SNI 03-4428-1997) Maksud pemeriksaannya ialah untuk mengetahui tingkat presentase kadar lumpur dari suatu agregat halus.

Pengujian Keausan (Abration) dengan Mesin Los Angeles (SNI 2417:2008). Tujuan dari percobaan ini untuk menentukan tingkat keausan agregat dengan menggunakan mesin los angeles dengan perbandingan berat benda yang lolos saringan No.12 $(1,7)$ dengan berat semula, dalam \%.

Pemeriksaan Partikel Pipih dan Lonjong (ASTM D4791-10). Tujuan dari pemeriksaan ini ialah menentukan indeks kepipihan dan kelonjongan suatu agregat yang dapat digunakan dalam campuran beraspal yang dinyatakan dalam \%.

Pengujian Kelekatan Agregat Terhadap Aspal (SNI 2439:2011).Pengujian ini dimaksudkan untuk menentukan kelekatan agregat terhadap aspal. Kelekatan agregat terhadap aspal ialah presentase luas permukaan batuan Pengujian Agregat Lolos Ayakan No.200 / 0,075 mm (SNI ASTM C117:2012) Maksud pengujian yaitu bertujuan untuk mengukur persentase jumlah bahan dalam agregat yang lolos saringan $200 / 0,075 \mathrm{~mm}$ sehingga berguna bagi perencana dan pelaksana pembangunan jalan.

\section{Pemeriksaan Karakteristik Aspal}

Metodologi yang digunakan dalam penelitian ini adalah Pengujian Penetrasi pada $25^{\circ} \mathrm{C}$ (SNI 2456:2011) Maksud pengujian yaitu untuk menentukan tingkat kekerasan aspal yaitu dalamnya suatu jarum masuk ke dalamaspal pada suhu tertentu yang dibebani dengan beban tertentu selama waktu tertentu.

Pengujian Titik Nyala $\left({ }^{\circ} \mathrm{C}\right)($ SNI 2433:2011), maksud pengujian yaitu untuk menentukan/mengetahui suhu dimana timbul nyala pada permukaan benda uji (aspal).

Pengujian Titik Lembek $\left({ }^{\circ} \mathrm{C}\right)$ (SNI 2434:2011), maksud pengujian yaitu untuk menentukan/mengetahui suhu di mana aspal mulai lembek.

Pengujian Berat Jenis (SNI 2441:2011), Maksud pengujian yaitu untuk menentukan berat jenis aspal terhadap air suling.

Pengujian Daktilitas pada $25^{\circ} \mathrm{C}$ (SNI 2432:2011), maksud pengujian yaitu untuk mengetahui kekenyalan aspal yang dinyatakan dengan panjang pemuluran aspal yang dapat tercapai hingga sebelum putus.

Pengujian Berat yang hilang (\%) (SNI-06-24411991), maksud pengujian untuk mengetahui kehilangan minyak pada aspal akibat pemanasan yang berulang dan pengujian ini juga bertujuan untuk mengukur perubahan kinerja aspal akibat kehilangan berat

\section{Pemeriksaan Berat Jenis Filler}

Pengujian Berat Jenis Filler mengacu pada standar rujukan SNI ASTM C136: 2012 Maksud dari pengujian ini ialah dapat menentukan berat jenis Filler yang digunakan sebagai bahan pengisi campuran aspal.

\section{Perencanaan Campuran}

Perencanaan campuran laston AC-BC yang digunakan berdasarkan metode grafis dan analitis yaitu dengan menggunakan tabel batasan spesifikasi gradasi campuran lalu menentukan gradasi ideal yaitu nilai tengah dari masing-masing batasan

spesifikasi gradasi. Selanjutnya menghitung proporsi dari setiap fraksi yaitu fraksi-fraksi halus dan fraksi filler serta kebutuhan aspal campuran. Terakhir gradasi campuran digambar dalam bentuk grafis gradasi untuk melihat apakah setiap prroporsi gradasi campuran masih masuk dalam batasan gradasi sesuai Spesifikasi Umum 2018 
http://ojs.ukipaulus.ac.id/index.php/pcej

Tabel 1. Rancangan Komposisi Campuran

\begin{tabular}{cccc}
\hline \multicolumn{2}{c}{ Ukuran Saringan } & $\begin{array}{c}\text { Spesifikasi BM 2018 } \\
(\%)\end{array}$ & $\begin{array}{c}\text { Gradasi } \\
\text { Rancangan (\%) }\end{array}$ \\
\cline { 1 - 2 } Inchi & Mm & & \\
\cline { 1 - 2 } $1 "$ & 25.000 & 100 & 100 \\
$3 / 4 "$ & 19.000 & $90-100$ & 95 \\
$1 / 2 "$ & 12.500 & $75-90$ & 82.5 \\
$3 / 8 "$ & 9.500 & $66-82$ & 74 \\
No.4 & 4.750 & $46-64$ & 55 \\
No.8 & 2.360 & $30-49$ & 39,5 \\
No.16 & 1.180 & $18-38$ & 28 \\
No.30 & 0.600 & $12-28$ & 20 \\
No.50 & 0.300 & $7-20$ & 13,5 \\
No.100 & 0.150 & $5-13$ & 9 \\
No.200 & 0.075 & $4-8$ & 6 \\
\hline
\end{tabular}

\section{Komposisi campuran}

Setelah semua bahan yang diperlukan memenuhi spesifikasi tahapan selanjutnya adalah menhitung komposisi campuran dan jumlah benda uji.

Perhitungan kadar aspal perkiraan awal :

Kadar aspal efektif min. $=0,6 \%$

Kadar aspal efektif mak $=1,2 \%$

Lolos ayakan No. $200=6 \%$

Kadar aspal rancangan maks $=10 \%$

Kadar aspal rancangan $\mathrm{min}=5 \%$

maka rancangan kadar aspal yang digunakan untuk campuran adalah minimal 5\%,5,5\%,6\%,6,5\% dan 7\%.

Berdasarkan Perhitungan kadar aspal perkiraan awal untuk gradasi agregat gabungan di atas maka didapatkan komposisi campuran beserta proporsi fillernya seperti pada tabel 2 .

Tabel 2. Komposisi campuran

\begin{tabular}{|c|c|c|c|c|c|c|}
\hline \multirow{2}{*}{ Material } & \multirow{2}{*}{ Uk. Saringan } & \multicolumn{5}{|c|}{ Kadar Aspal } \\
\hline & & $5 \%$ & $5,5 \%$ & $6,00 \%$ & $6,50 \%$ & $7,00 \%$ \\
\hline \multirow{5}{*}{ Agregat Kasar } & 1" & & & & & \\
\hline & 3/4" & & & & & \\
\hline & $1 / 2^{\prime \prime}$ & 43,18 & 43,00 & 42,82 & 42,64 & 42,45 \\
\hline & $3 / 8^{\prime \prime}$ & & & & & \\
\hline & No.4 & & & & & \\
\hline \multirow{6}{*}{ Agregat Halus } & No.8 & & & & & \\
\hline & №.16 & & & & & \\
\hline & No.30 & 46.27 & 4600 & 45.73 & 45.45 & 45.18 \\
\hline & No.50 & & & & & \\
\hline & No. 100 & & & & & \\
\hline & No. 200 & & & & & \\
\hline Filler & & 5,55 & 5,50 & 5,45 & 5,41 & 5,36 \\
\hline
\end{tabular}

Jumlah benda uji untuk penelitian ini seperti pada tabel 3.

Tabel 3. Jumlah benda uji

\begin{tabular}{ccc}
\hline Kadar aspal & $\begin{array}{c}\text { Marshall } \\
\text { Konvensional }\end{array}$ & $\begin{array}{c}\text { Marshall } \\
\text { Immertion }\end{array}$ \\
\hline $5 \%$ & 3 & \\
$5,5 \%$ & 3 & 3 \\
$6,00 \%$ & 3 & \\
$6,50 \%$ & 3 & \\
$7,00 \%$ & 3 & \\
\hline
\end{tabular}

\section{Pengujian Marshall Konvensional}

Pengujian Marshall Konvensional dilakukan untuk mengetahui nilai stabilitas dan kelelehan (flow), serta analisa kepadatan dan pori dari campuran padat yang terbentuk. Dalam hal ini benda uji atau briket beton aspal padat dibentuk dari gradasi agregat campuran tertentu, sesuai spesifikasi campuran. Sebelum membuat briket campuran aspal beton maka perkiraan kadar aspal optimum dicari dengan menggunakan rumus pendekatan. Pengujian Marshall untuk mendapatkan stabilitas dan kelelehan (flow) benda uji mengikuti prosedur SNI 06-2489-1991 AASHTO T245-90. Parameter Marshall yang dihitung antara lain: VIM, VMA, VFA, berat volume, dan parameter lain sesuai parameter yang ada pada spesifikasi campuran. Setelah semua parameter briket didapat, maka digambar grafik hubungan kadar aspal dengan parameternya yang kemudian dapat ditentukan kadar aspal optimumnya. Kadar aspal optimum adalah nilai tengah dari rentang kadar aspal yang memenuhi Marshall test modifikasi. Modifikasi alat Marshall ini terletak pada alat pemegang benda uji.

\section{Penentuan Kadar aspal optimum}

Kadar Aspal Optimum didapatkan dari nilai tertingi dari grafik hubungan stabilitas, kepadatan campuran yang dipadatkan dengan kadar aspal. Kadar Aspal

Optimum sesuai dengan fungsi campuran Laston AC-WC yaitu kedap air maka yang memiliki rongga dalam campuran atau void in mixture (VIM) terbesar karena jika tahan terhadap perendaman maka VIM yang kecil akan lebih tahan jika terendam.

\section{Pengujian Marshall Immersion}

Pengujian Marshall Immersion mengacu pada SNI 06-2489-1990. Tujuan pengujian ini adalah untuk mengetahui kemampuan campuran terhadap lama perendaman, suhu, dan air. atau indeks kekuatan sisa.

\section{ANALISIS DAN PEMBAHASAN}

\section{Karakteristik Material}

a. Agregat

Hasil pengujian terhadap agregat kasar dan halus sebagai berikut.

Hasil pengujian keausan agregat dengan menggunakan Alat Abrasi Los Angeles, diperoleh nilai ketahanan agregat kasar terhadap keausan dari Fraksi A adalah 4,60\%, Fraksi B adalah 4,92\%, Fraksi $C$ adalah $4,54 \%$ dan Fraksi $D$ adalah 4,22\%. Dari semua hasil pengujian, tiap fraksi memenuhi Spesifikasi Umum yaitu dengan nilai maksimum $8 \%$. Sehingga, dapat diketahui bahwa agregat tersebut dapat digunakan sebagai bahan lapisan 
permukaan jalan dapat tahan terhadap keausan akibat gesekan antara agregat dengan agregat atau agregat dengan roda kendaraan.

Hasil pengujian berat jenis dan penyerapan agregat kasar yang menggunakan dua sampel, diperoleh nilai untuk Berat Jenis Bulk adalah 2,58, berat jenis SSD adalah 2,62, berat jenis semu adalah 2,77 dan Penyerapan Air adalah 1,30\%. Spesifikasi Umum Bina Marga 2018, mensyaratkan untuk berat jenis bulk, berat jenis SSD dan berat jenis semu adalah minimal 2,5 dan penyerapan air maksimal $3 \%$ atau dapat dikatakan bahwa penyerapan agregatnya kecil.

Hasil pengujian berat jenis dan penyerapan agregat halus, diperoleh nilai untuk Berat Jenis Bulk adalah 2,54, Berat Jenis SSD adalah 2,56, Berat Jenis Semu adalah 2,60 dan Penyerapan Air adalah 0,91\%. Spesifikasi Umum Bina Marga 2018, yaitu untuk Berat Jenis Bulk, Berat Jenis, Berat Jenis Semu adalah minimal 2,5 dan Penyerapan Air maksimal adalah $3 \%$.

Hasil pengujian Analisa saringan dapat dilihat pada gambar 2.

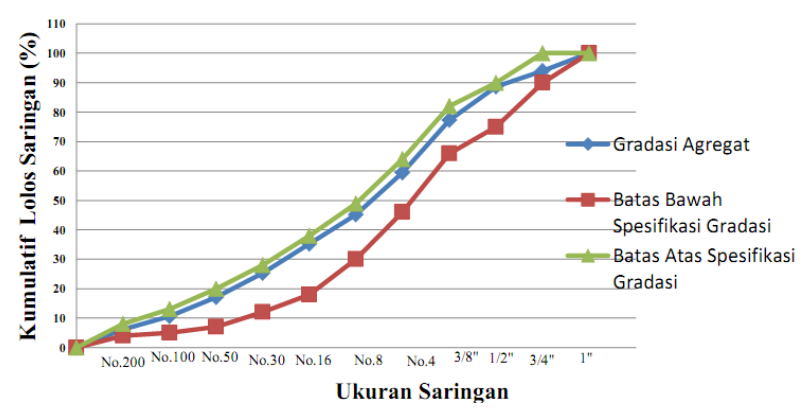

\section{Gambar 2. Hasil pengujian Analisa saringan}

Dari gambar 2 memperlihatkan hasil analisa saringan berupa gradasi agregat serta spesifikasinya dimana gradasi agregat berada ditengah antara batas atas dan batas bawah.

Hasil pengujian material lolos saringan No. 200 diperoleh hasil 2,41 persyaratan yaitu maksimal $10 \%$. Hasil pengujian ini menunjukkan material tersebut bersih dari lempung dan lanau.

Pengujian Kadar Lumpur Agregat Halus dengan menggunakan 2 (dua) sampel diperoleh hasil ratarata untuk nilai Sand Equivalen (SE) adalah 96,69\% dan kadar lumpur 3,31\%. Keduanya memenuhi Spesifikasi Umum Bina Marga 2018 yaitu minimal $60 \%$ untuk Sand Equivalen dan maksimal 5\% untuk kadar lumpur.

Hasil Pengujian Partikel Kepipihan dan Kelonjongan Agregat Kasar diperoleh partikel pipih yaitu $8,46 \%, 2,41 \%, 0,51 \%$, dan $0 \%$. Partikel lonjong yaitu $1,04 \%, 5,99 \%, 0,46 \%$ dan $0 \%$. Persyaratan yaitu maksimal $10 \%$.
Dari hasil pengujian Kelekatan Agregat Terhadap Aspal. Pengujian ini hanya bersifat visualisasi yang tidak melalui proses perhitungan. Nilai kelekatan ditentukan dari luas permukaan sampel yang terselimuti aspal (kurang dari 95\% atau lebih dari 95\%). Dari pengamatan ini dapat diketahui bahwa aspal dapat melekat dengan baik pada agregat.

\section{b. Aspal}

Aspal yang digunakan dalam penelitian ini adalah aspal minyak penetrasi 60/70. Hasil pengujian penetrasi diperoleh hasil untuk nilai penetrasi 67 $\mathrm{mm}$. Persyaratan Spesifikasi Umum Bina Marga 2018 yaitu minimal $60(0,1) \mathrm{mm}$ - maksimum 70 $(0,1) \mathrm{mm}$ Dari hasil pengujian daktilitas didapatkan nilai rata-rata $150 \mathrm{~cm}$. Persyaratan yaitu Min 100 $\mathrm{cm}$. Hasil pengujian titik lembek aspal didapatkan nilai rata-rata $51,7^{\circ} \mathrm{C}$ persyaratan yaitu antara $48-$ $58^{\circ} \mathrm{C}$. Hasil pengujian Titik Nyala didapatkan nilai rata-rata $300^{\circ} \mathrm{C}$. Syarat yang ditentukan dalam dalam Spesifikasi Umum Bina Marga 2018 yaitu Min $200^{\circ} \mathrm{C}$. Hasil Pengujian Berat Jenis didapatkan nilai rata-rata 1,051 gr/cc. persyaratan yaitu Min 1,0 $\mathrm{gr} / \mathrm{cc}$. Hasil pengujian penurunan berat aspal didapatkan nilai rata-rata $0,351 \%$ dimana persyaratan Maks 0,8\%. Hasil pengujian penetrasi pada TFOT hasil berat aspal didapatkan nilai ratarata 83,6\%. persyaratan Min $54 \%$.

\section{Marshall Konvensional}

Benda uji dibuat dengan kadar aspal untuk AC-BC yaitu : 5,00\%, 5.5\%, 6,00\%, 6,5\%, 7,00\%. Hasil perhitungan bulk spesific gravity dan effective spesific gravity dapat dilihat pada Tabel 4.

Tabel 4. Bulk Spesific Gravity dan Effective Spesific Gravity.

\begin{tabular}{cccccc}
\hline \multirow{2}{*}{ Nilai } & \multicolumn{5}{c}{ Kadar Aspal (\%) } \\
\cline { 2 - 6 } & 5,00 & 5,50 & 6,00 & 6,50 & 7,00 \\
\hline Bulk Spesific Gravity & 2,72 & 2,74 & 2,75 & 2,77 & 2,78 \\
Bulk Spesific Gravity & 2,76 & 2,77 & 2,79 & 2,80 & 2,83 \\
\hline
\end{tabular}

Hasil pengujian karakteristik marshall konvensional yang meliputi Stabilitas, VIM (Void in Mix), Flow, VMA (Void in Mineral Aggregate), VFB dapat dilihat pada tabel 5 .

Tabel 5. Nilai Karakteristik Marshall Konvensional

\begin{tabular}{cccccc}
\hline \multirow{2}{*}{$\begin{array}{c}\text { Kadar } \\
\text { Aspal (\%) }\end{array}$} & \multicolumn{4}{c}{ Karakteristik Marshall Konvensional dan Persyaratan } \\
\cline { 2 - 6 } & VIM (\%) & Stabilitas (Kg) & VFB (\%) & Flow (mm) & VMA (\%) \\
\cline { 2 - 6 }$-5 \%$ & Min 800 kg & Min 65\% & $2-4 \mathrm{~mm}$ & Min 14\% \\
\hline 5,00 & 4,82 & 882,00 & 68,43 & 3,28 & 15,26 \\
5,50 & 4,43 & 1681,00 & 72,41 & 3,17 & 16,05 \\
6,00 & 4,17 & 2593,55 & 75,39 & 2,94 & 16,96 \\
6,50 & 3,76 & 1805,88 & 78,79 & 3,55 & 17,73 \\
7,00 & 3,52 & 1608,96 & 81,12 & 3,85 & 18,65 \\
\hline
\end{tabular}




\section{a. VIM (Void in Mix)}

Nilai pengujian VIM seperti pada 5 dibuatkan grafik perbadingan dengan nilai kadart aspal seperti pada gambar 3.

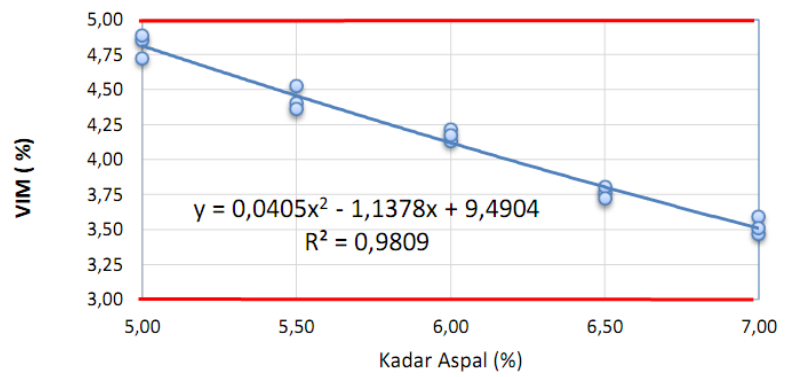

Gambar 3. Hubungan antara VIM dengan kadar aspal

dari gambar 3 terlihat penggunaan kadar aspal $5,00 \%$ - 7,00\% diperoleh nilai VIM antara 4,89\% $3,47 \%$. Nilai VIM ini memenuhi persyaratan. Dari gambar tersebut dapat diketahui penggunaan aspal yang banyak dalam campuran beraspal akan membantu mengisi rongga diantara agregat dalam campuran beraspal.

\section{b. Stabilitas}

Nilai stabilitas pada tabel 5 menunjukkan nilai antara $882,00 \mathrm{~kg}$ sampai dengan $2593,55 \mathrm{~kg}$. Nilai tersebut memenuhi persyaratan. Dari nilai tersebut dibuatkan grafik hubungan antara nilai stabilitas dengan kadar aspal seperti pada gambar 4 .

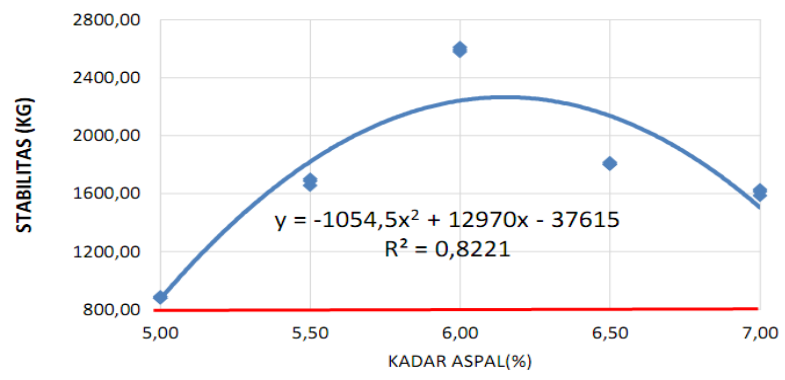

Gambar 4. Hubungan antara Stabilitas dengan kadar aspal

Berdasarkan gambar 4, dapat diketahui bahwa penggunaan kadar aspal yang sedikit dalam campuran akan menghasilkan selimut aspal yang tipis pada permukaan agregat yang mengakibatkan ikatan antar agregat (Interlocking) menjadi lemah sehingga stabilitas campuran kecil, tetapi jika aspal bertambah lagi maka ikatan antar agregat menjadi kuat atau stabilitas campuran besar. Kemudian jika aspal bertambah banyak lagi maka selimut aspal menjadi lebih tebal yang akan mengakibatkan ikatan antar agregat atau stabilitas campuran kembali menurun.

\section{c. VFB}

Hasil analisis terhadap VFB seperti pada tabel 5, menunjukkan nilai antara $68,43 \%$ sampai dengan $81,12 \%$ nilai tersebut memenuhi persyaratan. dari nilai tersebut dibuatkan grafik hubungan terhadap kadar aspal seperti pada gambar 5 .

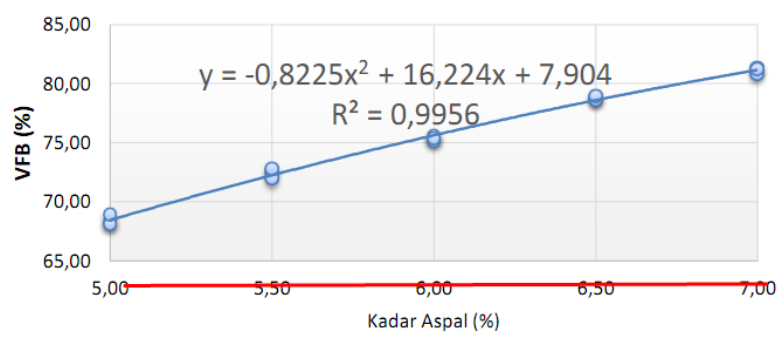

Gambar 5. Hubungan antara VFB dengan kadar aspal

Gambar 5 memperlihatkan trand garis semakin tinggi kadar aspal nilai VFB semakin meningkat. Ini memperlihatkan bahwa penggunaan kadar aspal yang sedikit mengurangi VFB, penggunaan kadar aspal yang banyak memperbesar VFB, begitu pun sebaliknya. Di mana aspal akan mengisi semua rongga yang ada dalam campuran dan dalam agregat.

\section{d. Flow}

Dari tabel 5, nilai flow dapat diketahui antara 3,17 $\mathrm{mm}$ sampai dengan $3,85 \mathrm{~mm}$. Nilai tersebut memenuhi persyaratan. Hasil perhitungan flow dibuatkan grafik dengan membandingkan dengan kadar aspal seperti pada gambar 6 .

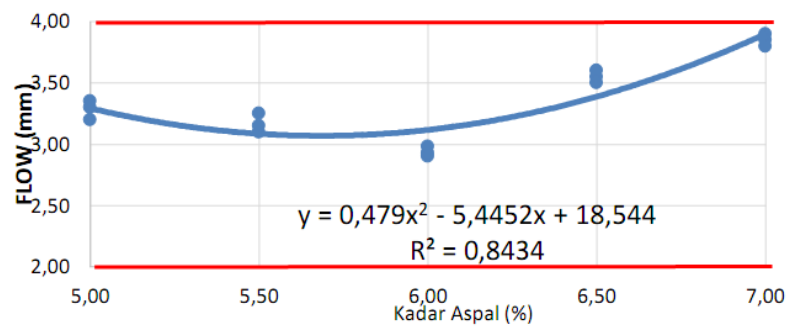

Gambar 6. Hubungan antara flow dengan kadar aspal

Berdasarkan Gambar 6 didapatkan jika penggunaan aspal dalam campuran beraspal kecil maka ikatan antar agregat berkurang yang menyebabkan kelenturan besar. Tetapi jika penggunaan aspal bertambah maka ikatan antar agregat dalam campuran menjadi lebih kuat yang mengakibatkan kelenturan campuran menurun, kemudian jika penggunaan aspal bertambah banyak lagi maka selimut aspal menjadi lebih tebal yang mengakibatkan kekuatan campuran berkurang tetapi kelenturan bertambah besar, artinya kekuatan campuran atau stabilitas akan berbanding terbalik dengan kelenturan campuran atau flow. 
e. VMA (Void in Mineral Aggregate)

Dengan menggunakan kadar aspal 5,00\%-7,00 \%. diperoleh nilai VMA antara $15,17 \%-18,71 \%$, seperti pada tabel 5, dimana nilai tersebut memenuhi persyaratan. Hal ini dipengaruhi oleh semakin banyak aspal yang digunakan, oleh karena fungsi aspal selain menyelimuti agregat (aspal efektif) juga berfungsi untuk mengisi rongga diantara agregat dan dalam partikel agregat. Dari Gambar 7 dapat disimpulkan bahwa semakin banyak aspal yang di gunakan maka rongga dalam agregat yang terisi aspal semakin besar sehingga nilai VMA akan meningkat. Hal ini dipengaruhi oleh penggunaan aspal yang banyak dimana saat pencampuran dan pemadatan, aspal akan menyelimuti agregat, mengisi rongga diantara agregat dan mengisi rongga dalam agregat.

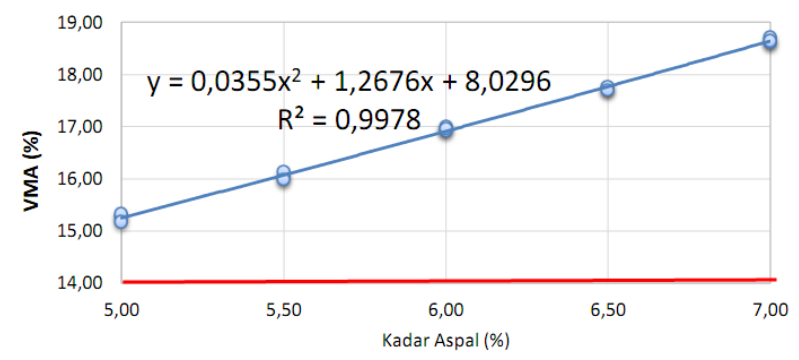

Gambar 7. Hubungan antara VMA dengan kadar aspal

\section{Penentuan Kadar Aspal Optimum}

Berdasarkan hasil analisis pengujian Marshall karakteristik pada tabel 5 dapat ditentukan kadar aspal praktis dalam campuran beton aspal yaitu kadar aspal yang memenuhi semua kriteria atau karakteristik marshall campuran dan kadar aspal praktis tersebut adalah rentang kadar aspal 5,00\% - 7,00\%. Namun untuk kadar aspal optimum dipilih yang memiliki stabilitas yang paling tinggi yaitu pada kadar aspal 6,0\% karena lapisan laston ACBC merupakan lapisan antara atau lapisan penopang yang harus memberikan dukungan yang kuat bagi lapasan di atasnya.

\section{Indeks Kekuatan Sisa}

Setelah penentuan kadar aspal optimum, maka langkah selanjutnya adalah membuat benda uji berdasarkan kadar aspal optimum, yaitu $6,00 \%$ kemudian direndam selama \pm 24 jam pada suhu \pm $60^{\circ} \mathrm{C}$.

Tabel 6. Hasil pengujian indeks kekuatan sisa

\begin{tabular}{cccc}
\hline Kadar & \multicolumn{3}{c}{ Nilai Stabilitas } \\
\cline { 2 - 4 } Aspal (\%) & Konvensional & Immertion & IKS \\
\hline 6,00 & 1234,04 & 1178,88 & 95,53 \\
6,00 & 1240,93 & 1185,78 & 95,56 \\
6,00 & 1247,82 & 1199,57 & 93,13 \\
\hline Rata-rata & 1240,93 & 1188,08 & 95,74 \\
\hline
\end{tabular}

Untuk mendapatkan nilai indeks perendaman/indeks kekuatan sisa dari campuran. adapun hasil pengujian indeks kekuatan sisa campuran, dapat dilihat pada tabel 6 .

Nilai indeks kekuatan sisi didapatkan dari hasil pengujian rasio stabilitas dengan membandinkan stabilitas dari benda uji Marshall setelah direndam dalam suhu $60^{\circ} \mathrm{C}$ dalam waterbath selama 24 jam terhadap stabilitas benda uji Marshall dengan perendaman 30 menit.

Dari hasil pengujian Marshall Immertion diperoleh indeks perendaman sebesar $95,74 \%$ dengan kadar aspal $6,0 \%$. Nilai indeks perendaman ini telah memenuhi standar yang ditetapkan oleh Badan Penelitian dan Pengembangan Departemen Pekerjaan Umum Tahun 2018 yaitu minimal 90\%.

\section{KESIMPULAN}

Berdasarkan dari hasil penelitian maka dapat disimpulkan sebagai berikut :

1. Karakteristik agregat yang berasal dari Gunung Posi'padang Balla Kabupaten Mamasa, serta aspal penetrasi 60/70 untuk campuran LASTON AC-BC memenuhi standar Bina Marga.

2. Komposisi campuran LASTON AC-BC yaitu agregat kasar $42,45 \%$, agregat halus $45,18 \%$, Filler 5,36\% dengan kadar aspal optimum 7\%.

3. Hasil uji Marshall Immersion (Indeks Kekuatan Sisa) pada campuran Laston AC-BC memenuhi standar/sesifikasi Bina Marga 2018, yaitu minimal $90 \%$.

\section{DAFTAR PUSATAKA}

[1] G. Rusbintardjo, 2013, Aspal- Bahan Perkerasan Jalan, 1 ed. Semarang, Indonesia: UNISSULA Press,

[2] S. Sukirman, 2007, Beton Aspal Campuran Panas, Edisi Kedua. Jakarta: Yayasan Obor Indonesia.

[3] R. Rachman, 2012, "Evaluation of Asbuton Filler Performance in Asphalt Hot Rollers (HRA) Mortar Mixes," Jumal IIm. Adiwidia, vol. 4, no. 1, Art. no. 1.

[4] R. Rachman, 2012, "Evaluasi Kinerja Filler asbuton dalam Campuran Mortar Hot Rol Asphalt (HRA)," Jumal IIm. Adiwidia, vol. 4, no. 1 , Art. no. 1.

[5] Direkorat Jenderal Bina Marga, 2018, Spesifikasi Umum Bina Marga 2018 untuk Pekerjaan Konstruksi Jalan dan Jembatan. Jakarta Indonesia: Kementerian Pekerjaan Umum dan Perumahan Rakyat. 
[6] Alpius dan A. Kusuma, 2019, "Performance of Laston AC-WC Mixture Using Asbuton LGA and Fakfak Materials," Jour Adv Res. Dyn. Control Syst., vol. 11, no. 7, Art. no. 7.

[7] C. Kamba, 2013, "Pengaruh Penentuan Kadar Aspal Optimum Terhadap Kualitas Desain Campuran Beraspal," dalam Seminar Nasional Teknik Sipil UKIPaulus, Makassar, vol. 1, hlm. $58-69$.

[8] J. Tandibua, R. Rachman, dan J. Tanijaya, 2020, "Study of Laston BC Durability and Permeability Using Coconut Shell Addition Materials," Bali, Indonesia, , vol. 419, doi: 10.1088/1755-1315/419/1/012101.

[9] Sumardi, R. Rachman, dan J. Tanijaya, 2019, "Study of the Use Bagasse Ash as a Filler Replacement to Characteristics Asphalt
Concrete," Int. J. Sci. Eng. Sci., vol. 3, no. 8, Art. no. 8, doi: 10.5281/zenodo.3408011.

[10] R. Rachman, 2020, "Pemanfaatan Batu Gunung Bottomale Toraja Utara sebagai Campuran Laston," J. Tek. Sipil Dan Teknol., vol. 6, no. 1, Art. no. 1.

[11] Fani. L. A, Irianto, Elizabeth, dan Alpius, 2019 "Pemanfaatan Agregat Sungai Wanggar Kabupaten Nabire Sebagai Bahan Campuran AC-WC dan AC-BC," Paulus Civ. Eng. J. Ojsukipaulusacid, vol. 1, no. 2, Art. no. 2.

[12] C. Kamba dan R. Rachman, 2018, "Marshall Characteristics Test On Hot Rolled Sheet Base Combine Using Nickel Slag For Half Gap Graded," Int. J. Innov. Sci. Eng. Technol., vol. 5, no. 3, Art. no. 3. 